\title{
Preparation of an electrochemical sensor for measuring the silicon content in molten iron
}

\author{
Liangchen $\mathrm{Ju}^{\mathrm{a}}$, Hui Lu ${ }^{\mathrm{b}}$, Wenkuan Man ${ }^{\mathrm{a}}$, Yang $\mathrm{Li}^{\mathrm{c}}$, Min Guo ${ }^{* a}$, Mei Zhang ${ }^{\mathrm{a}}$
}

\section{ABSTRACT}

A silicon sensor for measuring the silicon content in molten iron that included a new membrane electrode was synthesized by coating a slurry of $\mathrm{CaF}_{2}, \mathrm{SiO}_{2}$ and $5 \%$ Polyvinyl alcohol (PVA) onto the surface of a $\mathrm{ZrO}_{2}(\mathrm{MgO})$ solid electrolyte tube, followed by sintering in a high purity $\mathrm{Ar}$ atmosphere. The influences of the preparation conditions, such as the chemical composition, solid $\left(\mathrm{CaF}_{2}+\mathrm{SiO}_{2}\right.$ powder $)$ to liquid (5\% PVA solution) ratio and sintering temperature, on the coating layer adhesive properties, active ingredients and detection performance of the formed auxiliary electrode layer were systematically investigated. It is indicated that the synthesized coating layer showed strong adhesive properties and the main active ingredients were $\mathrm{SiO}_{2}\left(\mathrm{ZrSiO}_{4}\right)$ solid particles-CaO$\cdot \mathrm{MgO} \cdot 2 \mathrm{SiO}_{2}$ solid solution under the optimum preparation conditions. The as-prepared silicon sensor, which was used to detect the silicon content in molten iron at $1450{ }^{\circ} \mathrm{C}$, exhibited superior performance. When the silicon content ranged from 0.5 to $1.5 \%$ in liquid iron, the testing result from the silicon sensor with a response time of $15 \mathrm{~s}$ and steady time greater than $30 \mathrm{~s}$

${ }^{a}$ School of Metallurgical and Ecological Engineering, University of Science and Technology Beijing, Beijing 100083, PR China. E-mail: guomin@ustb.edu.cn, Fax: +861062334926

${ }^{\mathrm{b}}$ School of Materials Science and Engineering, Beifang University of Nationalities, Yinchuan, Ningxia, 750021, PR China

${ }^{\mathrm{c}}$ The State Key Laboratory for Refractories and Metallurgy, School of Materials and Metallurgy, Wuhan University of Science and Technology, Wuhan 430081, China. 
agreed well with the values from the chemical analysis method.

Keywords: Solid electrolyte; Silicon sensor; Auxiliary coating layer; Molten iron; Membrane electrode

\section{Introduction}

Silicon content, an important reference value for blast furnace operation, has a significant influence on blast furnace conditions and fuel consumption in steel production. Appropriately controlling the silicon content in molten iron is beneficial to reduce the generation of slag in the steelmaking process and to shorten the smelting time. Therefore, it is important to determine the silicon content rapidly and accurately in iron processing. Generally, the silicon content is influenced by different factors, and it is difficult to precisely determine the silicon content through analysis of the raw material alone [1]. At present, chemical analysis and spectral analysis are usually used to measure the silicon content at the factory. However, much time is needed to determine the silicon content through these methods; as a result, the silicon content in the molten iron cannot be adjusted in a timely manner. Therefore, metallurgists have been seeking rapid and accurate methods to determine the silicon content during ironmaking.

Two main methods, including the thermoelectric potential method [2] and the electrochemical method [3-7], are used to measure the silicon content in molten iron rapidly. The thermoelectric potential method is used to determine the silicon content by measuring the thermoelectric potential difference between two metals' contact 
point at different temperatures. L.K. Liang et al. [8] measured the silicon content in blast furnace iron for about $10 \mathrm{~s}$ with the absolute error of $\pm(0.03 \sim 0.05) w t . \%$ Si by using this method. However, this method exhibited poor stability, and the equipment suffered a great deal of abrasion with long-term use. Given the shortcoming of the thermoelectric potential method, the electrochemical method, with its potential short response time, high accuracy and good stability, is useful for determining the silicon content. The electrochemical method determines the silicon content of molten iron by measuring the electric potential difference between the inside and outside surfaces of the membrane electrode $[9,10]$. Due to the high temperature encountered when measuring the silicon content in molten iron, the stability of membrane electrode under the high temperature must be settled. Rich $\mathrm{SiO}_{2}$ mullite and silicate slag membrane electrodes were developed successfully at first $[11,12]$. However, these types of membrane electrodes were difficult to prepare and showed poor stability at high temperatures. The $\mathrm{ZrO}_{2}$ solid electrolyte type oxygen sensor, being mature and having good performance with a response time of $10 \mathrm{~s}$ and an accuracy of $\pm 5 \%$, has been widely used to measure the oxygen content in molten steel [13]. Considering that the $\mathrm{ZrO}_{2}$ solid electrolyte type oxygen sensor has been commercialized and the rapid equilibrium between $[\mathrm{O}]_{\text {diss }},[\mathrm{Si}]_{\text {diss }}\left(\right.$ where $[\mathrm{Si}]_{\text {diss }}$ and $[\mathrm{O}]_{\text {diss }}$ are the concentrations of $\mathrm{Si}$ and $\mathrm{O}$ dissolved in molten iron, respectively.) and compounds of silicon and oxygen at high temperature [14-20], some researchers have tried to develop a novel membrane electrode by coating auxiliary material on the $\mathrm{ZrO}_{2}$ solid electrolyte to determine the silicon content in molten iron. M. Iwase [21, 22] initially developed a 
silicon sensor with a $\mathrm{ZrO}_{2}+\mathrm{ZrSiO}_{4}$ coating on the $\mathrm{ZrO}_{2}$ solid electrolyte. Though the auxiliary material had good adhesion to the solid electrolyte, the membrane electrode needed to be sintered at $1450{ }^{\circ} \mathrm{C}$ for approximately $20 \mathrm{~h}$, and the deviation in the silicon content measured was about $\pm(0.03 \sim 0.1) \mathrm{wt}$.\% with silicon content in the range of $0.1 \sim 0.7 \mathrm{wt} . \%$. To simplify the preparation process and improve the repeatability, researchers have begun to use $\mathrm{SiO}_{2}+\mathrm{CaF}_{2}$ as the auxiliary material to prepare the silicon sensor. However, no studies to date have studied the relationship between the effective ingredients and silicon sensor performance.

In this paper, a novel membrane electrode, $\mathrm{ZrO}_{2}-\mathrm{SiO}_{2}-\mathrm{CaO} \cdot \mathrm{MgO} \cdot 2 \mathrm{SiO}_{2}$, was prepared for use in a silicon sensor by coating $\mathrm{CaF}_{2}+\mathrm{SiO}_{2}$ powder onto a $\mathrm{ZrO}_{2}$ solid electrolyte surface and subjecting it to high temperatures. The effects of the preparation conditions, such as the chemical composition of the coating, the solid to liquid ratio of the $\mathrm{CaF}_{2}+\mathrm{SiO}_{2}$ coating and a 5\% PVA solution, as well as the sintering temperature on the adhesive properties of the coating layer and active ingredient were studied in detail. In addition, the influence of auxiliary material on the silicon sensor performance was also discussed. This paper may provide a simple novel method of synthesizing a $\mathrm{ZrO}_{2}-\mathrm{SiO}_{2}-\mathrm{CaO} \cdot \mathrm{MgO} \cdot 2 \mathrm{SiO}_{2}$ silicon sensor with a short response time, good stability and high accuracy.

\section{Theoretical Background of the silicon sensor}

Taking a $\mathrm{SiO}_{2}$-containing type silicon sensor as an example, the electrochemical cells can be represented as

$$
\text { Mo }\left|\mathrm{Cr}+\mathrm{Cr}_{2} \mathrm{O}_{3}\right| \mathrm{ZrO}_{2}(\mathrm{MgO})\left|\mathrm{SiO}_{2}\right|[\mathrm{Si}]_{\text {diss }} \mid \mathrm{Mo}
$$


The reactions of the electrodes and the cell can be depicted as

reaction at reference electrode: $\quad 2 / 3 \mathrm{Cr}_{2} \mathrm{O}_{3}+4 \mathrm{e} \leftrightharpoons 4 / 3 \mathrm{Cr}+2 \mathrm{O}^{2-}$

reaction at working electrode: $\quad 2 \mathrm{O}^{2-} \leftrightharpoons 2[\mathrm{O}]_{\mathrm{diss}}+4 \mathrm{e}$

Overall reaction:

$$
2 / 3 \mathrm{Cr}_{2} \mathrm{O}_{3} \leftrightharpoons 2[\mathrm{O}]_{\text {diss }}+4 / 3 \mathrm{Cr}
$$

The equilibrium reaction between the solid $\mathrm{SiO}_{2}$ (membrane) and liquid $[\mathrm{Si}]_{\text {diss }}$ interface is rapid due to the high temperature and can be expressed as

$$
[\mathrm{Si}]_{\mathrm{diss}}+2[\mathrm{O}]_{\mathrm{diss}} \leftrightharpoons \mathrm{SiO}_{2(\mathrm{~s})}
$$

Combining the equilibrium reaction (4) and reaction (3), the overall reaction of the silicon sensor based on the $\mathrm{SiO}_{2}$-containing membrane can be summarized as

$$
2 / 3 \mathrm{Cr}_{2} \mathrm{O}_{3}+[\mathrm{Si}]_{\mathrm{diss}} \leftrightharpoons \mathrm{SiO}_{2(\mathrm{~s})}+4 / 3 \mathrm{Cr}
$$

Given that the $\mathrm{SiO}_{2}$ in the membrane exists in the solid state during the testing process, the pure substance is chosen as the standard state and the activity of $\mathrm{SiO}_{2}$ $\left(\mathrm{a}_{\mathrm{SiO}_{2}}\right)$ is 1 [23]. Considering the influence of electron conduction in the solid electrolyte membrane at high temperatures, the relationship between the electric potential difference and oxygen partial pressure is given by equation (6) (S8, ESI), and the formula is true for divalent anionic conductors.

$$
E=\frac{R T}{F} \ln \frac{P_{\left(C r / C r_{2} O_{3}\right)}^{1 / 4}+P_{e}^{1 / 4}}{p_{\left[O O_{d i s s}\right.}^{1 / 4}+P_{e}^{1 / 4}}
$$

Based on the equilibrium reaction (4), equation (6) can be depicted as

$$
E=\frac{R T}{F} \ln \frac{P_{\left(C r / C_{\left.r_{2} O_{3}\right)}\right.}^{1 / 4}+P_{e}^{1 / 4}}{\left(K \cdot a_{[S i]}\right)^{-1 / 4}+P_{e}^{1 / 4}}
$$

where $\mathrm{E}(\mathrm{V})$ is the electric potential difference of the silicon sensor, $\mathrm{K}$ is the equilibrium constant of Eq.(4), $\mathrm{R}\left(8.314 \mathrm{~J} \cdot \mathrm{mol}^{-1} \cdot \mathrm{K}^{-1}\right)$ is the gas constant, $\mathrm{T}(\mathrm{K})$ is the 
temperature, $\mathrm{F}\left(96500 \mathrm{C} \cdot \mathrm{mol}^{-1}\right)$ is the Faraday constant, $\mathrm{a}_{[\mathrm{Si}]}$ is the Henrian activity of silicon referring to a $1 \mathrm{wt} . \%$ solution, $\mathrm{P}_{\left(\mathrm{Cr}_{\mathrm{Cr} 2 \mathrm{O}}\right)}(\mathrm{atm})$ is the oxygen partial pressure of the $\left(\mathrm{Cr}+\mathrm{Cr}_{2} \mathrm{O}_{3}\right)$ reference electrode, and $\mathrm{Pe}(\mathrm{atm})$ denotes the oxygen partial pressure at which the ionic conductivity and n-type electronic conductivity are equal.

By using the Henrian activities, the silicon content in the molten iron can be calculated by

$$
\log \alpha_{[S i]}=\log [\% S i]+e_{S i}^{S i}[\% S i]+e_{S i}^{C}[\% C]
$$

where [\% i] is the mass concentration (wt.\%) of element $\mathrm{i}$ dissolved in molten iron and $\mathrm{e}_{\mathrm{b}}^{\mathrm{a}}$ is the interaction parameter of elements $\mathrm{a}$ to $\mathrm{b}$ in molten iron, which can be expressed as follows [24]:

$$
\begin{gathered}
e_{S i}^{S i}=34.5 / T+0.089 \\
e_{S i}^{C}=380 / T-0.023
\end{gathered}
$$

\section{Experimental procedure}

\subsection{Materials}

The solid electrolyte tube $\mathrm{ZrO}_{2}(2.1 \% \mathrm{MgO})$, reference electrode $\mathrm{Cr}+\mathrm{Cr}_{2} \mathrm{O}_{3}$, high temperature cement, and filling material $\mathrm{Al}_{2} \mathrm{O}_{3}$ were supplied by the University of Science \& Technology Beijing. Molybdenum rods (3 $\mathrm{mm}$ in diameter), molybdenum wire and ferrosilicon were supplied by Beijing Research Institute of Mining and Metallurgy. Ferrosilicon was provided by the Shougang Group, with 82 wt.\% Si. Polyvinyl alcohol (PVA) and analytical reagent (AR) grade calciumfluoride $\left(\mathrm{CaF}_{2}\right)$, calcium oxide $(\mathrm{CaO})$, magnesium oxide $(\mathrm{MgO})$ and silicon dioxide $\left(\mathrm{SiO}_{2}\right)$ were purchased from Sinopharm Chemical Reagent Co., Ltd. 
The oxygen sensor purchased from University of Science \& Technology Beijing consisted of a solid electrolyte $\mathrm{ZrO}_{2}(2.1 \% \mathrm{MgO})$ and reference electrode $\mathrm{Cr}+\mathrm{Cr}_{2} \mathrm{O}_{3}$. The detection accuracy of the oxygen sensor was approximately $\pm 3 \mathrm{mV}$ for $10-1000$ ppm oxygen content.

\subsection{Experimental procedure}

\subsubsection{Preparation of the auxiliary coating layer}

The auxiliary coating slurry was prepared by mixing $\mathrm{CaF}_{2}, \mathrm{SiO}_{2}$ and a $5 \%$ PVA organic binder with 10 wt. $\%$ to 40 wt. $\% \mathrm{CaF}_{2}$ and a solid to liquid ratio of $10 \mathrm{~g} / 10$ $\mathrm{mL}$ or $15 \mathrm{~g} / 10 \mathrm{~mL}$. The slurry was evenly painted on the outside surface of the zirconia tube. After drying at room temperature for $24 \mathrm{~h}$ and at $80{ }^{\circ} \mathrm{C}$ for $48 \mathrm{~h}$, the zirconia tube coated with the slurry was sintered from $1325{ }^{\circ} \mathrm{C}$ to $1500{ }^{\circ} \mathrm{C}$ for $30 \mathrm{~min}$ under the protection of high purity Ar.

\subsubsection{Preparation of silicon sensor}

The zirconia tube (height: $34 \mathrm{~mm}$, diameter: $5 \mathrm{~mm}$ ), which had been sintered with the slurry coating on the surface, was filled with approximately one-fourth of the reference electrode powder, $\mathrm{Cr}+\mathrm{Cr}_{2} \mathrm{O}_{3}$, and three-fourths of $\mathrm{Al}_{2} \mathrm{O}_{3}$ power. After the molybdenum wire was inserted into the center of the tube, the zirconia tube was encapsulated by high temperature cement. The membrane electrode $\mathrm{ZrO}_{2}-\mathrm{SiO}_{2}-\mathrm{CaO} \cdot \mathrm{MgO} \cdot 2 \mathrm{SiO}_{2}$ for the silicon sensor was obtained, and its schematic diagram of preparation and structure are shown in Fig. S1 (ESI) and Fig. 1, respectively.

\subsubsection{Detection of the silicon content in molten iron}


Approximately $100 \mathrm{~g}$ of cast iron and ferrosilicon between $0.5 \mathrm{~g}$ and $4.0 \mathrm{~g}$ were added together into a carbon crucible, which was heated to $1450{ }^{\circ} \mathrm{C}$ in a stream of high purity Ar inside a SiMo resistance furnace (GSL-06-16LA). After the metallic charge was molten at $1450{ }^{\circ} \mathrm{C}$ for half an hour, the silicon sensor, which used a molybdenum rod as a counter electrode, was immersed into the molten iron for approximately $1 \mathrm{~min}$ to measure the silicon activity. The silicon content in the molten iron changed from 0.5 to 1.5 wt. $\%$ as a result of adding different amounts of ferrosilicon. A digital multimeter (Gwinstek, GDM-8261A) was used to record a data point every $0.5 \mathrm{~s}$ and plot the curve of the electric potential difference against time. The experiment was repeated at least 3 times under the same conditions. Moreover, the oxygen sensor was also used to compare the results with those measured with the silicon sensors at the same time, and a sample of molten iron was taken for chemical analysis. A schematic diagram of the as-prepared silicon sensor is illustrated in Fig. 1.

\subsection{Analysis and characterization}

The chemical composition of the ferrosilicon was analyzed by X-ray fluorescence (XRF-1800, Japan). The silicon and carbon contents of the molten iron were measured by an Inductive Coupled Plasma Emission Spectrometer (ICP, TELEDYNE, Leeman labs). The surface morphology and composition of the auxiliary electrode coating layer were investigated by a mineral liberation analyzer (MLA 250), with a Scanning Electron Microscope (SEM) operated at $20 \mathrm{kV}$ and linked with an Energy Dispersive Spectrometer (EDS) attachment.

\section{Results and discussion}




\subsection{Adhesion properties of the auxiliary coating layer to the zirconia solid electrolyte tube}

From Fig. 1, it can be seen that the membrane electrode was the most important part of the silicon sensor to determine the silicon content in molten iron. Therefore, good adhesion of the auxiliary coating layer to the zirconia solid electrolyte tube needed to be achieved in the preparation of the membrane electrode. In this paper, the effects of different preparation conditions, such as the coating chemical composition, sintering temperature and solid to liquid ratio of the mixed $\mathrm{CaF}_{2}+\mathrm{SiO}_{2}$ powder and PVA solution on the adhesive property of the auxiliary coating layer, were investigated in detail, and the results are summarized in Table 1. It can be seen from Table 1 that the lowest sintering temperature, which resulted in the auxiliary coating layer having good adhesion to the zirconia tube, showed a declining trend with the $\mathrm{CaF}_{2}$ content increasing from $10 \%$ to $40 \%$. Fixing a solid to liquid ratio of $10 \mathrm{~g} / 10$ $\mathrm{mL}$ and increasing the sintering temperature were beneficial to the strong adhesion of the auxiliary coating layer with the same $\mathrm{CaF}_{2}$ content. Based on the above analysis, it can be concluded that the suitable preparation conditions for the synthesis of the auxiliary coating layer with strong adhesion were as follows: a solid to liquid ratio of $10 \mathrm{~g} / 10 \mathrm{~mL}$ and sintering temperatures of 1400 to $1450{ }^{\circ} \mathrm{C}$ with a $\mathrm{CaF}_{2}$ content of $20 \%$ and 1350 to $1400{ }^{\circ} \mathrm{C}$ with a $\mathrm{CaF}_{2}$ content of $30 \%$ to $40 \%$, respectively.

The auxiliary coating layer, which had good adhesion to the solid electrolyte tube after being sintered, was analyzed by SEM and EDS. SEM images of the coating layer on the surface of zirconia tube under the different preparation conditions are shown in 
Fig. 2. Based on the comprehensive analysis of the composition of the auxiliary coating layer with EDS, the average analysis results on the characteristic areas of the coating layer surfaces in Fig. 2 are summarized in Table 2. From the EDS analysis results, it can be observed that no $\mathrm{F}$ existed in the auxiliary coating layer. This might be due to the following reaction that allowed $\mathrm{SiF}_{4}$ to evaporate during the coating process, according to previous reports [25-26]:

$$
2 \mathrm{CaF}_{2}+\mathrm{SiO}_{2}=2 \mathrm{CaO}+\mathrm{SiF}_{4}
$$

Moreover, it is indicated from Fig. 2 and Table 2 that the formed phases (the chemical compositions) of the auxiliary coating layers depended on both sintering temperature and the chemical components (e.g., the amount of $\mathrm{CaF}_{2}$ ) of the coating layers. Specifically, when the amount of $\mathrm{CaF}_{2}$ was fixed at $20 \%$, the formed phases of the auxiliary coating layers were the same with sintering temperature increasing from 1400 to $1450{ }^{\circ} \mathrm{C}$, based on the related phase diagram of the $\mathrm{ZrO}_{2}(\mathrm{MgO})-\mathrm{CaO}-\mathrm{SiO}_{2}$ system (Fig. S2-Fig. S4, ESI) and SEM/EDS analysis of the coating layer surfaces. The auxiliary coating layers mainly contained solid particles of $\mathrm{SiO}_{2}$ and $\mathrm{ZrSiO}_{4}$ as well as a solid solution of $\mathrm{CaO} \cdot \mathrm{MgO} \cdot 2 \mathrm{SiO}_{2}$ (with a softening point of approximately $\left.1290{ }^{\circ} \mathrm{C}\right)$. The areas of asperities, as shown in Fig. 2(a-c), was mainly composed of $\mathrm{SiO}_{2}$ particles coated with a solid solution of $\mathrm{CaO} \cdot \mathrm{MgO} \cdot 2 \mathrm{SiO}_{2}$. When the $\mathrm{CaF}_{2}$ content increased to $30 \%$, the compositions of auxiliary coating layers changed to $\mathrm{SiO}_{2}, \mathrm{CaSiO}_{3}, \mathrm{ZrSiO}_{4}$ and $\mathrm{CaO} \cdot \mathrm{MgO} \cdot 2 \mathrm{SiO}_{2}$ with sintering temperature at $1350{ }^{\circ} \mathrm{C}$. The asperities illustrated in Fig. 2(d) mainly consisted of $\mathrm{SiO}_{2}$ and $\mathrm{CaSiO}_{3}$ coated with $\mathrm{CaO} \cdot \mathrm{MgO} \cdot 2 \mathrm{SiO}_{2}$. Further increasing the sintering temperature to $1375{ }^{\circ} \mathrm{C}$ and 
$1400{ }^{\circ} \mathrm{C}$, the coating layer was only composed of $\mathrm{ZrSiO}_{4}$ and $\mathrm{CaO} \cdot \mathrm{MgO} \cdot 2 \mathrm{SiO}_{2}$. In addition, when the $\mathrm{CaF}_{2}$ content was up to $40 \% \mathrm{CaF}_{2}$, the formed phases changed from $\mathrm{CaSiO}_{3}$ and $\mathrm{CaO} \cdot \mathrm{MgO} \cdot 2 \mathrm{SiO}_{2}$ at $1350{ }^{\circ} \mathrm{C}$ to only $\mathrm{CaO} \cdot \mathrm{MgO} \cdot 2 \mathrm{SiO}_{2}$ at more than $1375^{\circ} \mathrm{C}$. The main phases of the coating layers under different preparation conditions are summarized in Table 3.

Based on the analysis of surface components and distribution of components, it was found that the adhesion properties of the coating layer were mainly affected by the content and distribution of the formed solid solution $\mathrm{CaO} \cdot \mathrm{MgO} \cdot 2 \mathrm{SiO}_{2}$. The coating layer would have good adhesion to the zirconia tube only when there was enough $\mathrm{CaO} \cdot \mathrm{MgO} \cdot 2 \mathrm{SiO}_{2}$ to coat the solid $\mathrm{SiO}_{2}$ and $\mathrm{CaSiO}_{3}$ particles. However, a low $\mathrm{CaF}_{2}$ content and low sintering temperature reduced the generation of the solid solution in the coating layer, which had a negative effect on the adhesion of the coating layer. As shown in Table 1 , both increasing the $\mathrm{CaF}_{2}$ content and sintering temperature were beneficial to the coating layer adhesion. Moreover, the solid to liquid ratio of the mixed $\mathrm{CaF}_{2}+\mathrm{SiO}_{2}$ powder and PVA solution was also one of the important influencing factors that determined the adhesion property of the coating layer. A high solid to liquid ratio would increase the thickness of the coating layer, which would cause an inhomogeneous distribution of the solid solution and relatively lower content of the formed $\mathrm{CaO} \cdot \mathrm{MgO} \cdot 2 \mathrm{SiO}_{2}$, resulting in poor adhesion of the coating layer, which could even fall off the surface of the $\mathrm{ZrO}_{2}$ tube. The results are in accordance with those summarized in Table 1. To ensure the strong adhesion of the coating layer, the $\mathrm{CaF}_{2}$ content should be more than $20 \%$ and the solid to liquid ratio should be approximately 
$10 \mathrm{~g} / 10 \mathrm{~mL}$.

\subsection{The active component of the as-prepared membrane electrode and its}

\section{response ability}

The response ability of the silicon sensor mainly depended on the equilibrium reaction between the active component of the membrane and the $[\mathrm{Si}]_{\mathrm{diss}}$ in the molten iron. According to the above analysis, many silicon-containing components, such as $\mathrm{CaO} \cdot \mathrm{MgO} \cdot 2 \mathrm{SiO}_{2}, \mathrm{CaSiO}_{3}$ and $\mathrm{ZrSiO}_{4}$, in addition to solid $\mathrm{SiO}_{2}$, were formed in the coating layer (Table 3). Therefore, the influence of these components on the silicon detection ability needed to be considered. Given that the variation of the standard Gibbs free energy ( $\Delta G^{\theta}$ ) of reaction (12) was similar to that of reaction (4), the equilibrium constants (K) were almost the same for reaction (4) and reaction (12) at the same temperature (Eq. S9-Eq. S10, ESI). Therefore, according to equation (7), the presence of $\mathrm{ZrSiO}_{4}$ had no negative influence on measuring the silicon content in theory, indicating that the formed $\mathrm{ZrSiO}_{4}$, like the $\mathrm{SiO}_{2}$ in the membrane, could be regarded as the active ingredient to determine the silicon content in molten iron.

$$
\mathrm{ZrO}_{2}+[\mathrm{Si}]_{\mathrm{diss}}+2[\mathrm{O}]_{\mathrm{diss}} \leftrightharpoons \mathrm{ZrSiO}_{4}
$$

As for the other silicon compounds, such as $\mathrm{CaO} \cdot \mathrm{MgO} \cdot 2 \mathrm{SiO}_{2}$ and $\mathrm{CaSiO}_{3}$, the $\Delta G^{\theta}$ values of reactions (13-14) were more negative than that of reaction (4) as calculated in ESI, so the equilibrium constants $(\mathrm{K})$ of reactions (13-14) were quite different than that of reaction (4) at the same temperature (Eq. S9, Eq S11, Eq S12, ESI). According to equation (7), the existence of $\mathrm{CaO} \cdot \mathrm{MgO} \cdot 2 \mathrm{SiO}_{2}$ and $\mathrm{CaSiO}_{3}$ may have a significant effect on measuring silicon content in principle. 


$$
\begin{gathered}
1 / 2 \mathrm{CaO}+1 / 2 \mathrm{MgO}+[\mathrm{Si}]_{\text {diss }}+2[\mathrm{O}]_{\text {diss }} \leftrightharpoons 1 / 2 \mathrm{CaO} \cdot \mathrm{MgO} \cdot 2 \mathrm{SiO}_{2} \\
\mathrm{CaO}+[\mathrm{Si}]_{\text {diss }}+2[\mathrm{O}]_{\text {diss }} \leftrightharpoons \mathrm{CaSiO}_{3}
\end{gathered}
$$

To verify the effects of these components on the detection properties of the as-prepared silicon sensor, all of the samples that had good adhesion of the auxiliary coating layer to the zirconia tube, as indicated in Table 1, were investigated. The testing results are summarized in Table 3 . It can be seen from Table 3 that the silicon sensors synthesized from $20 \%$ and $30 \% \mathrm{CaF}_{2}$ had good stability in measuring the silicon content. The typical curves of the two types of silicon sensors illustrated in Fig. 3(a) and Fig. 3(b) show that the platform fluctuation of the electric potential difference was less than $3 \mathrm{mV}$, suggesting good stability of the silicon sensors. The response time was approximately $15 \mathrm{~s}$, and the stable time was approximately $30 \mathrm{~s}$, further confirming that $\mathrm{SiO}_{2}$ and $\mathrm{ZrSiO}_{4}$ could be used as the active components of the membrane to measure silicon content. The existence of $\mathrm{CaO} \cdot \mathrm{MgO} \cdot 2 \mathrm{SiO}_{2}$ in the membrane had no negative influence on the platform stability. More importantly, the presence of a liquid phase of $\mathrm{CaO} \cdot \mathrm{MgO} \cdot 2 \mathrm{SiO}_{2}$ at the testing temperature could ensure the short response time of the silicon sensor, which was ascribed to the fact that silicon and oxygen could diffuse freely in the coating layer. In addition, as shown in Table 3, the silicon sensors synthesized with $40 \% \mathrm{CaF}_{2}$ at different sintering temperatures could not obtain the stable curve (Fig. 3(c)), indicating that $\mathrm{CaSiO}_{3}$ and $\mathrm{CaO} \cdot \mathrm{MgO} \cdot 2 \mathrm{SiO}_{2}$ could not be used as active components of the membrane to measure the silicon content.

\subsection{Testing of the silicon sensor}


4.3.1 The effects of different preparation conditions on the performance of the as-prepared silicon sensor

The effects of different preparation conditions on the performance of the as-prepared silicon sensor were summarized in Table 4. All the silicon sensors synthesized under the conditions listed in Table 4 (a solid (20 wt.\% $\mathrm{CaF}_{2}+80$ wt.\% $\mathrm{SiO}_{2}$ mixed powder) to liquid (5\% PVA solution) ratio of $10 \mathrm{~g} / 10 \mathrm{~mL}$, sintering temperature and time of $1400{ }^{\circ} \mathrm{C}$ or $1435{ }^{\circ} \mathrm{C}$ or $1450{ }^{\circ} \mathrm{C}$ for $30 \mathrm{~min}$; a solid (30 wt. $\%$ $\mathrm{CaF}_{2}+70$ wt. $\% \mathrm{SiO}_{2}$ mixed powder) to liquid (5\% PVA solution) ratio of $10 \mathrm{~g} / 10 \mathrm{~mL}$, sintering temperature and time of $1350{ }^{\circ} \mathrm{C}$ or $1375{ }^{\circ} \mathrm{C}$ or $1400{ }^{\circ} \mathrm{C}$ for $30 \mathrm{~min}$ ) could be used to measure the silicon content in molten iron.

The values of the $[\% \mathrm{Si}]_{\text {measured }}$ (Table 4 ) were calculated from the $\mathrm{E}_{[\mathrm{Si}]}$ measured by the as-prepared silicon sensor according to equations (7-8). From Table 4, it can be seen that the electric potential difference of the oxygen sensor and the silicon sensor were different, suggesting that the formed membrane was more sensitive to the silicon content than to the oxygen content and could be used as the working electrode of the silicon sensor.

As for the silicon sensors synthesized under the same preparation conditions as shown in Table 4, the testing errors of the electric potential differences were generally less than $5 \mathrm{mV}$ for the same silicon content $(0.53 \mathrm{wt} . \% \mathrm{Si}$ or $0.92 \mathrm{wt} . \% \mathrm{Si})$ in the molten iron. The corresponding errors of $[\% \mathrm{Si}]_{\text {measured }}$ were generally less than $6 \%$ (0.53 wt.\% Si) and 20\% (0.92 wt.\% Si) compared with the actual values of the silicon contents, suggesting good repeatability for the prepared sensors. As for the silicon 
sensors synthesized under different preparation conditions, that is to say, the comparison covers all sensors which responded to silicon in the melt, irrespective of the level of optimisation in the preparation procedure, the errors of $[\% \mathrm{Si}]_{\text {measured }}$ and the actual value for the same silicon content were almost no more than $20 \%$, indicating that the silicon sensors had good accuracy and could meet the requirements of the ironworks. Considering the performance of the silicon sensor, sintering temperature and $\mathrm{CaF}_{2}$ content, the optimum preparation conditions for the membrane electrode were as follows: a solid (20 wt. $\% \mathrm{CaF}_{2}+80$ wt. $\% \mathrm{SiO}_{2}$ mixed powder) to liquid (5\% PVA solution) ratio of $10 \mathrm{~g} / 10 \mathrm{~mL}$, sintering temperature and time of $1400{ }^{\circ} \mathrm{C}$ for $30 \mathrm{~min}$, as described in this paper.

4.3.2 The effect of different silicon contents in molten iron on the performance of the formed silicon sensor

The silicon sensor synthesized under the optimum conditions was used to measure molten iron with silicon contents varying from $0.5 \%$ to $1.5 \%$. Table 5 gives the measured results of the silicon sensors with different silicon contents in molten iron, and Fig. 4 illustrates the comparison of chemical analysis results by ICP with the silicon sensor analysis results. The red line in Fig. 4 was the ideal state at which the measured value of $[\% \mathrm{Si}]$ and the actual value in molten iron was equal. From Table 5, it can be observed that there were deviations between the measured values and actual values. The difference values were generally less than $20 \%$ compared with the actual values of the silicon contents when the silicon content ranged from 0.5 to $1.5 \%$ in molten iron, indicating that the as-prepared silicon sensor could be applied in industry. 


\section{Conclusion}

A silicon sensor consisting of a working membrane electrode and molybdenum rod counter electrode was utilized to detect the silicon content in molten iron rapidly and accurately. The membrane electrode was synthesized by coating a slurry of $\mathrm{CaF}_{2}$, $\mathrm{SiO}_{2}$ and 5\% PVA on the surface of a $\mathrm{ZrO}_{2}(\mathrm{MgO})$ tube and sintering in a high purity Ar atmosphere. The optimum preparation conditions for the membrane electrode were as follows: a solid (20 wt. $\% \mathrm{CaF}_{2}+80$ wt. $\% \mathrm{SiO}_{2}$ mixed powder) to liquid (5\% PVA solution) ratio of $10 \mathrm{~g} / 10 \mathrm{~mL}$ and sintering at $1400{ }^{\circ} \mathrm{C}$ for $30 \mathrm{~min}$. When the silicon content ranged from 0.5 to $1.5 \%$ in liquid iron, the testing result based on the obtained silicon sensor with a response time of $15 \mathrm{~s}$ and steady time greater than $30 \mathrm{~s}$ agreed well with the value based on the chemical analysis method.

\section{Acknowledgements}

This work was financially supported by the National Basic Research Program of China (No. 2014CB643401, No. 2013AA032003), the National Science Foundation of China (No. 51372019).

\section{References}

[1] F.S. Li, H.P. He, L.S. Li, L.F. Li, L. Daotze, A study on aluminum sensor for steel melt, Sens. Actuators B 63 (2000) 31-34.

[2] Y.J. Wan, H.P. Fan, H.L. Wu, P. Gao, C. Yang, Rapid determination of silicon contents in molten iron in BF production, Iron and Steel 28 (1993) 10-14. 
[3] Z.H. Jiang, Principle and working conditions of electrochemical sensors with auxiliary electrode, J. Iron Steel Res. Int. 6 (1995) 61-68.

[4] D.J. Fray, The use of solid electrolytes as sensors for applications in molten metals, Solid State Ionics 86-88 (1996) 1045-1054.

[5] G.A. Giffin, M. Piga, S. Lavina, M.A. Navarra, Characterization of sulfated-zirconia/Nafion composite membranes for proton exchange membrane fuel cells, J. Power Sources 198 (2012) 66-75.

[6] S. Martion, Q. Li, T. Steenberg, J.O. Jensen, Binderless electrodes for high-temperature polymer electrolyte membrane fuel cells, J. Power Sources 272 (2014) 559-566.

[7] K. Chebout, A. Iratni, A. Bouremana, S. Sam, A. Keffous, N. Gabouze, Electrical characterization of ethanol sensing device based on Vanadium oxide/Porous $\mathrm{Si} / \mathrm{Si}$ structure, Solid State Ionics 253 (2013) 164-168.

[8] L.K. Liang, X.Y. Ma, H. Yang, G.H. Sun, Z.W. Guo, L.Y. Xiong, B.H. Xi, Y.C. Guo, Quick determination of silicon content in iron-base Alloy by Thermo-Emf, Journal of Northeastern University (Natural Science) 16 (1995) 372-375.

[9] Y.R. Hong, C.J. Jin, L.S. Li, J.L. Sun, An application of the electrochemical sulfur sensor in steelmaking, Sens. Actuators B 87 (2002) 13-17.

[10] E.D. Xing, L.Q. Liang, Y.J. Dong, W.M. Huang, An oxygen reduction sensor based on a novel type of porous carbon composite membrane electrode, Chin. Chem. Lett. 2015.

[11] X.M. Yang, Y.S. Liu, Determination of silicon content in hot metal by means of 
electrochemical silicon sensor, Engineering Chemistry \& Metallurgy 13 (1992) 264-271.

[12] W.Y. Lu, Y.W. Tian, C.Z. Wang, J.Q. Gao, Study on measurement of silicon activity using silicon sensor in carbon saturated iron melt, J. Chin. Rare Earth Soc. 24 (2006) 5-8.

[13] J.F. Xia, Q. Li, D.Y. Jiang, Development of oxygen sensor technique on liquid steel, Adv. Ceram. 4 (2009) 21-25.

[14] S. Colominas, J. Abella, Evaluation of potentiometric oxygen sensors based on stabilized zirconia for molten $44.5 \%$ lead-55.5\% bismuth alloy, Sens. Actuators B 145 (2010) 720-725.

[15] H.S. Noh, K.J. Yoon, B.K. Kim, H.J. Je, H.W. Lee, J.H. Lee, J.W. Son, The potential and challenges of thin-film electrolyte and nanostructured electrode for yttria-stabilized zirconia-base anode-supported solid oxide fuel cells, J. Power Sources 247 (2014) 105-111.

[16] S. Lu, J. Lin, J.C. Chen. Progress of research on zirconia oxygen sensor, Instrument Technique and sensor. 3 (2007) 1-3.

[17] W.Z. Deng, Y. Li, Y.S. Ding. Recent progress of metallurgical sensors based on oxygen sensor as an auxiliary electrode, J. Materials and Metallurgy 13 (2014) $161-170$.

[18] S. Yoon, T. Noh, W. Kim, J. Choi, H. Lee, Structural parameters and oxygen ion conductivity of $\mathrm{Y}_{2} \mathrm{O}_{3}-\mathrm{ZrO}_{2}$ and $\mathrm{MgO}-\mathrm{ZrO}_{2}$ at high temperature, Ceram. Int. 39 (2013) 9247-9251. 
[19] T. Liu, L. Li, J.K. Yu. An electrochemical sulfur sensor based on $\mathrm{ZrO}_{2}(\mathrm{MgO})$ as solid electrolyte and $\mathrm{ZrS}_{2}+\mathrm{MgS}$ as auxiliary electrode, Sens. Actuators B 139 (2009) $501-504$

[20] A.K. Rivai, T. Kumagai, M. Takahashi. Performance of oxygen sensor in lead-bismuth at high temperature, Prog. Nucl. Energ. 50 (2008) 575-581.

[21] M. Iwase, Developments in zirconia sensors during the 1980's - Laboratory and in-plant applications in iron and steelmaking, Proceedings of the 1st International Chromium Steel and Alloys Congress, Cape Town. Johannesburg, SAIMM. 2 (1992) $49-61$

[22] M. Iwase, Rapid determination of silicon activities in hot metal by means of solid state electrochemical sensors equipped with an auxiliary electrode, Scand J Metall. 17 (1988) 50-56.

[23] H.J. Guo, Physical Chemistry of Metallurgy, second ed., Press Metall. Industry, Beijing, 2006.

[24] G. K. Sigworth, J. F. Elliot, The thermodynamics of liquid dilute iron alloys, Met. Sci. 8 (1974) 298-310.

[25] Y.S. Xu, Y.X. Zou, F.L. Liu, A study of the equilibrium between $\mathrm{HF}-\mathrm{H}_{2} \mathrm{O}$ gas and slags of the $\mathrm{CaO}-\mathrm{CaF}_{2}$ and $\mathrm{CaO}-\mathrm{SiO}_{2}-\mathrm{CaF}_{2}$ system, Acta Metall. Sin. 7 (1964) 24-31. [26] Q.J. Qi, J.Z. Liu, X.Y. Cao, J.H. Zhou, S.X. Zhang, K.F. Cen, Stability of $\mathrm{CaF}_{2}$ at high temperature, Environmental Science 23 (2002) 111-114. 


\section{Figure captions}

Fig. 1 Schematic diagram of the as-prepared silicon sensor

Fig. 2 SEM images of the coating layers on the surface of the silicon sensor under the different preparation conditions. (a) $20 \%, 10 \mathrm{~g} / 10 \mathrm{~mL}, 1400{ }^{\circ} \mathrm{C}$; (b) $20 \%, 10 \mathrm{~g} / 10 \mathrm{~mL}, 1435{ }^{\circ} \mathrm{C}$; (c) $20 \%$, $10 \mathrm{~g} / 10 \mathrm{~mL}, 1450{ }^{\circ} \mathrm{C}$; (d) $30 \%, 10 \mathrm{~g} / 10 \mathrm{~mL}, 1350{ }^{\circ} \mathrm{C}$; (e) $30 \%, 10 \mathrm{~g} / 10 \mathrm{~mL}, 1375{ }^{\circ} \mathrm{C}$; (f) $30 \%$, $10 \mathrm{~g} / 10 \mathrm{~mL}, 1400{ }^{\circ} \mathrm{C}$; (g) $40 \%, 10 \mathrm{~g} / 10 \mathrm{~mL}, 1350{ }^{\circ} \mathrm{C}$; (h) $40 \%, 10 \mathrm{~g} / 10 \mathrm{~mL}, 1375{ }^{\circ} \mathrm{C}$; (i) $40 \%$, $10 \mathrm{~g} / 10 \mathrm{~mL}, 1400{ }^{\circ} \mathrm{C}$

Fig. 3 Testing results of the as-prepared silicon sensors and partially enlarged images. (a) 20\% $\mathrm{CaF}_{2}$; (b) $30 \% \mathrm{CaF}_{2}$; (c) $40 \% \mathrm{CaF}_{2}$

Fig. 4 Comparison of the chemical analysis results by ICP with the silicon sensor measured results 


\section{Digital multimeter}

High temperature

Filling material

Auxiliary electrode

$$
\mathrm{Al}_{2} \mathrm{O}_{3}
$$

Zirconia tube

Reference electrode

$\mathrm{Cr} / \mathrm{Cr}_{2} \mathrm{O}_{3}$

\section{$-$}

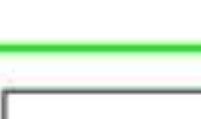

$-$

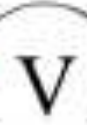

Molybdenum

\section{Counter} electrode

Molten iron

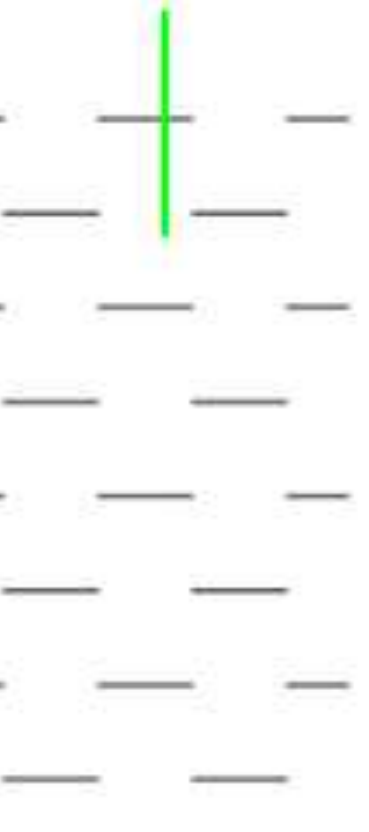




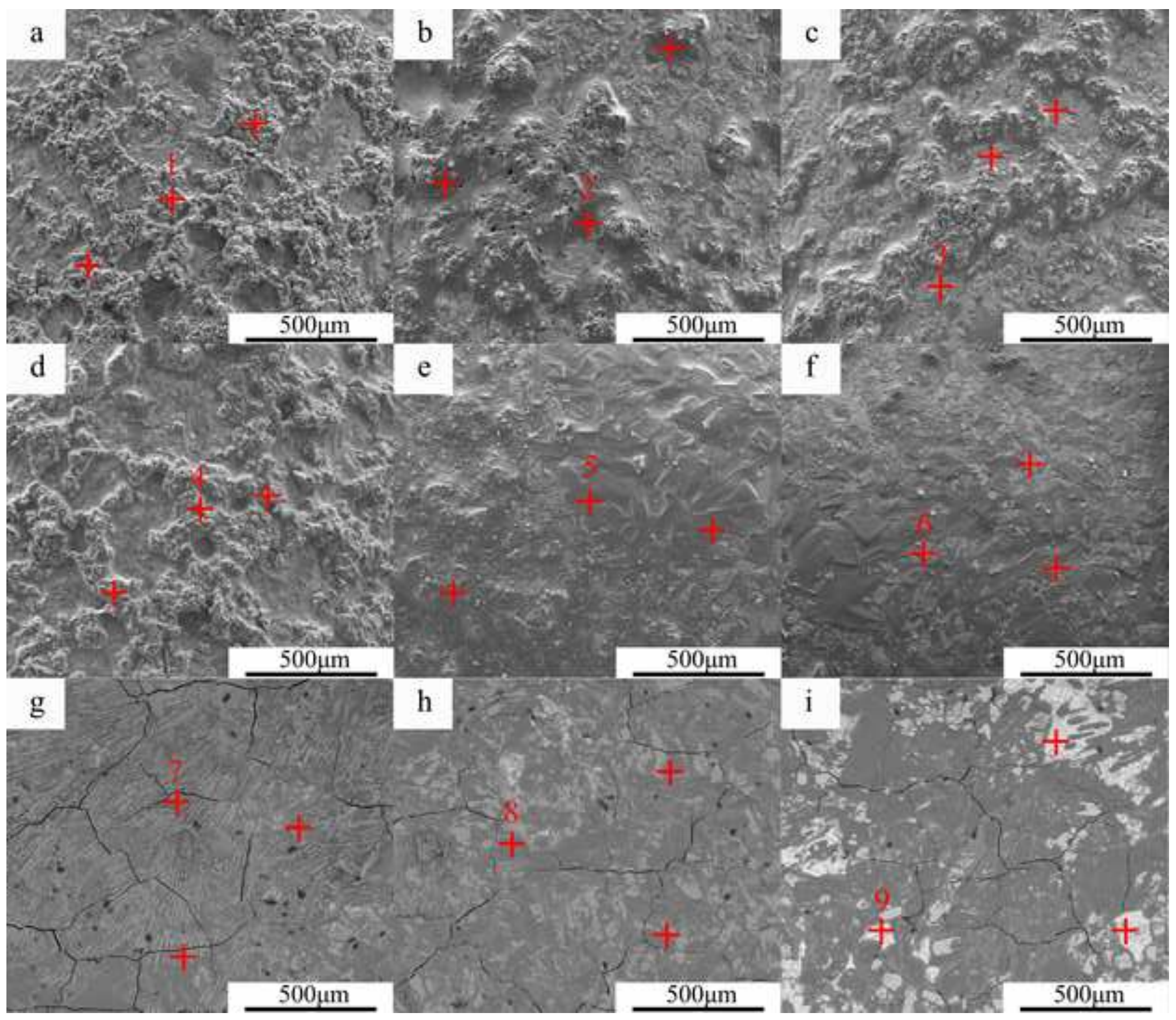



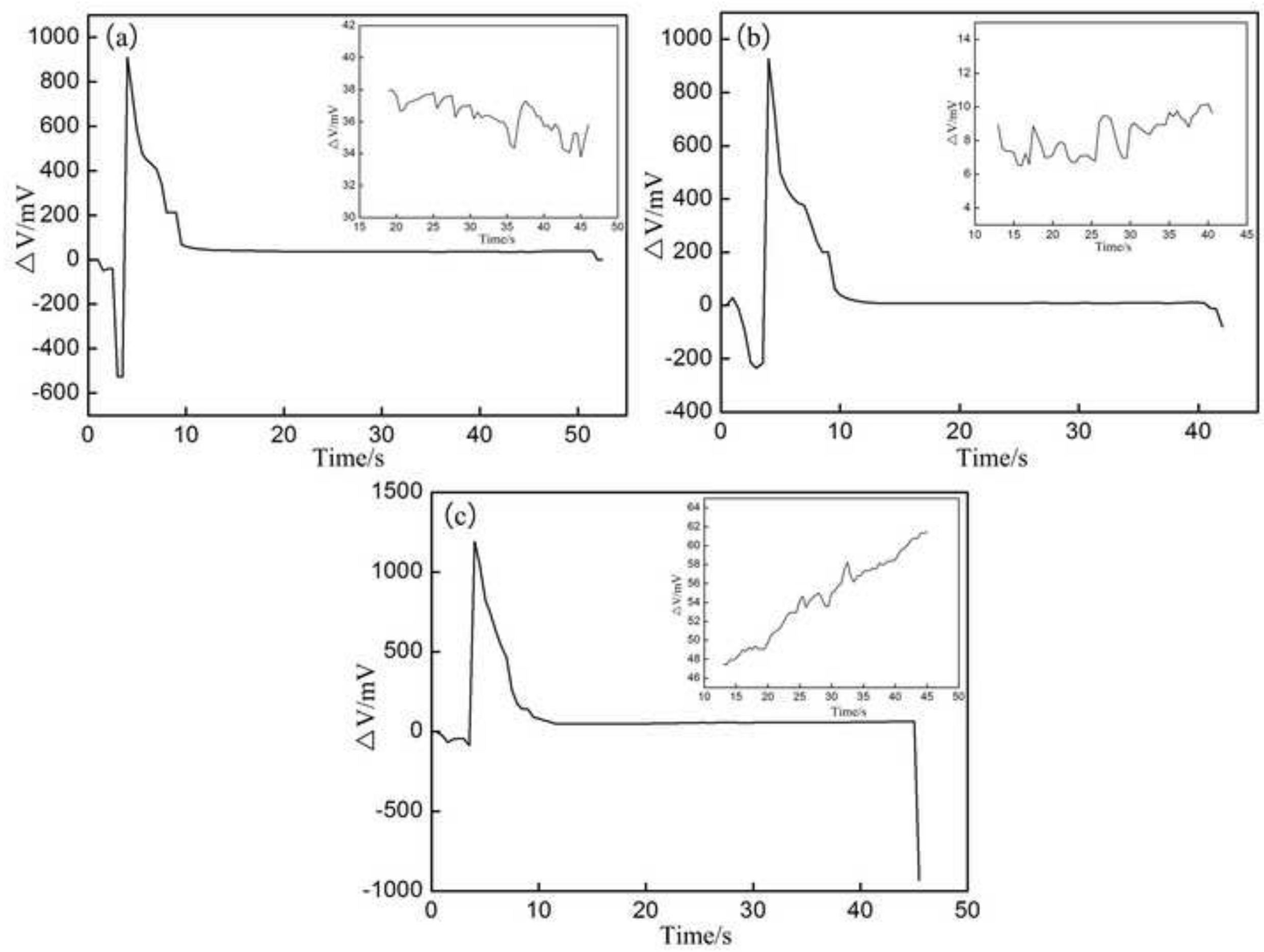


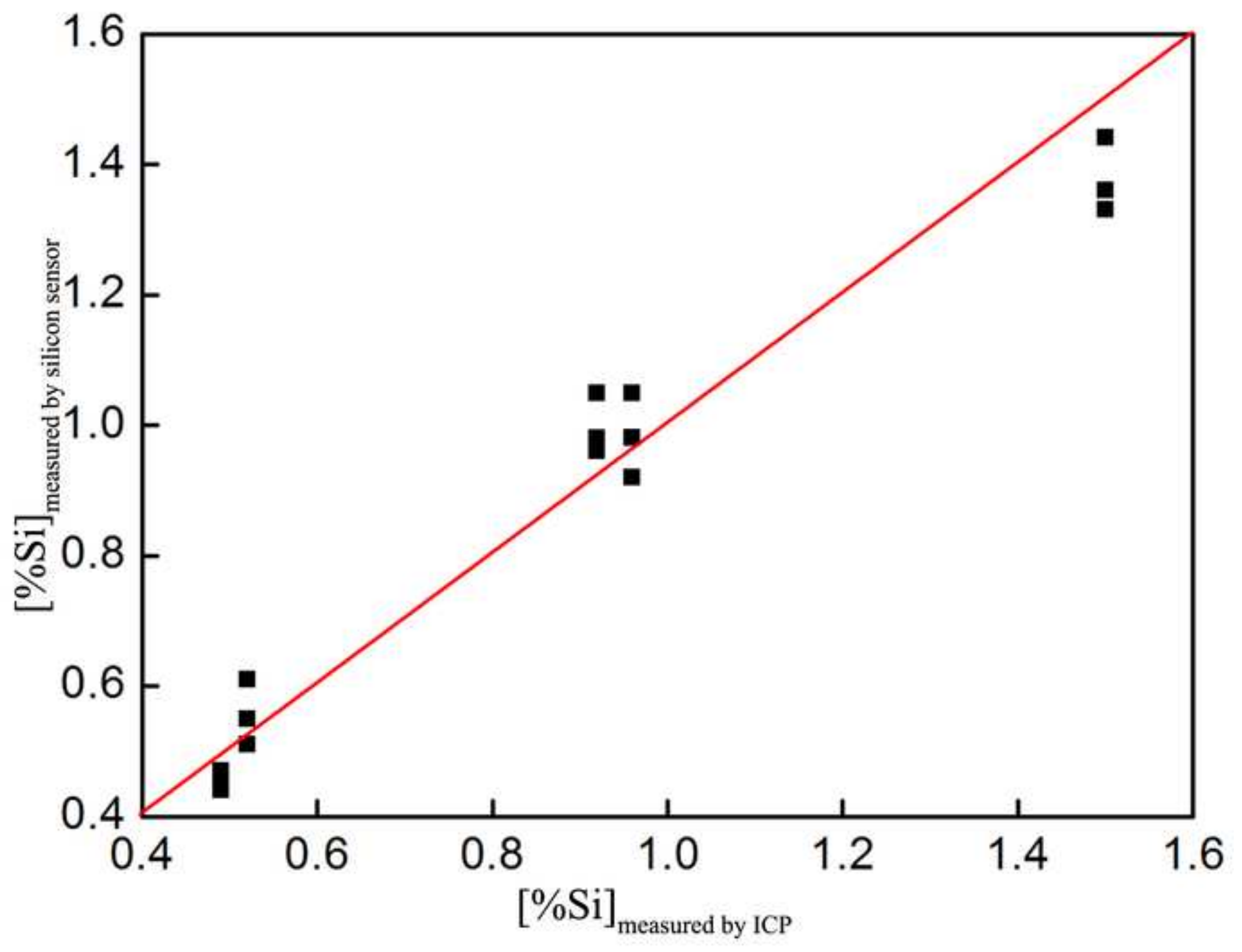




\section{Table captions}

Table 1 Preparation conditions and adhesive property results of the auxiliary coating layer

Table 2 The elemental content of the different areas indicated in Fig. 2

Table 3 The main compositions of coating layer and testing results of the as-prepared silicon sensor

Table 4 The measured results of the silicon sensors under the different preparation conditions

Table 5 The measured results of the silicon sensors for different silicon contents in molten iron 
Table 1 Preparation conditions and adhesive property results of the auxiliary coating layer

\begin{tabular}{|c|c|c|c|}
\hline \multicolumn{3}{|c|}{ Preparation conditions } & \multirow{2}{*}{$\begin{array}{c}\text { Adhesive } \\
\text { property result }\end{array}$} \\
\hline $\begin{array}{c}\mathrm{CaF}_{2} \text { content } \\
\text { (wt.\%) }\end{array}$ & Mixed powder (g) / PVA solution (mL) & Sintering temperature $\left({ }^{\circ} \mathrm{C}\right)$ & \\
\hline \multirow{4}{*}{10} & $10 / 10$ & 1450 & Falling off \\
\hline & $10 / 10$ & 1500 & Falling off \\
\hline & $15 / 10$ & 1450 & Falling off \\
\hline & $15 / 10$ & 1500 & Falling off \\
\hline \multirow{6}{*}{20} & $10 / 10$ & 1375 & Falling off \\
\hline & $10 / 10$ & 1400 & Good adhesion \\
\hline & $10 / 10$ & 1435 & Good adhesion \\
\hline & $10 / 10$ & 1450 & Good adhesion \\
\hline & $15 / 10$ & 1400 & Falling off \\
\hline & $15 / 10$ & 1450 & Falling off \\
\hline \multirow{6}{*}{30} & $10 / 10$ & 1325 & Falling off \\
\hline & $10 / 10$ & 1350 & Good adhesion \\
\hline & $10 / 10$ & 1375 & Good adhesion \\
\hline & $10 / 10$ & 1400 & Good adhesion \\
\hline & $15 / 10$ & 1350 & Falling off \\
\hline & $15 / 10$ & 1400 & Falling off \\
\hline \multirow{6}{*}{40} & $10 / 10$ & 1325 & Falling off \\
\hline & $10 / 10$ & 1350 & Good adhesion \\
\hline & $10 / 10$ & 1375 & Good adhesion \\
\hline & $10 / 10$ & 1400 & Good adhesion \\
\hline & $15 / 10$ & 1350 & Falling off \\
\hline & $15 / 10$ & 1400 & Falling off \\
\hline
\end{tabular}


Table 2 The elemental content of the different areas indicated in Fig. 2

\begin{tabular}{|c|c|c|c|c|c|}
\hline \multirow{2}{*}{ Area } & \multicolumn{5}{|c|}{ Element content (at.\%) } \\
\hline & $\mathrm{Si}$ & $\mathrm{Ca}$ & $\mathrm{Mg}$ & $\mathrm{Zr}$ & $\mathrm{O}$ \\
\hline 1 & 34.75 & - & - & - & 65.25 \\
\hline 2 & 19.10 & 9.31 & 13.44 & - & 58.15 \\
\hline 3 & 19.07 & - & - & 21.09 & 59.83 \\
\hline 4 & 29.53 & 10.91 & 1.72 & - & 57.84 \\
\hline 5 & 19.52 & 11.09 & 12.92 & - & 56.47 \\
\hline 6 & 16.84 & - & - & 20.25 & 62.91 \\
\hline 7 & 20.73 & 18.88 & - & - & 60.39 \\
\hline 8 & 17.64 & 10.00 & 11.64 & - & 60.72 \\
\hline 9 & - & - & - & 32.86 & 67.14 \\
\hline
\end{tabular}


Table 3 The main compositions of coating layer and testing results of the as-prepared silicon sensor

\begin{tabular}{|c|c|c|c|c|}
\hline \multicolumn{2}{|c|}{ Preparation conditions } & \multirow[b]{2}{*}{ Main compositions } & \multicolumn{2}{|c|}{ Testing results } \\
\hline $\begin{array}{c}\mathrm{CaF}_{2} \text { content } \\
(\text { wt. } \%)\end{array}$ & $\begin{array}{c}\text { Sintering } \\
\text { temperature }\left({ }^{\circ} \mathrm{C}\right)\end{array}$ & & Response & $\begin{array}{l}\text { Stability of the } \\
\text { curve }\end{array}$ \\
\hline \multirow{3}{*}{20} & 1400 & $\mathrm{SiO}_{2}{ }^{*}, \mathrm{ZrSiO}_{4}{ }^{*}, \mathrm{CaO} \cdot \mathrm{MgO} \cdot 2 \mathrm{SiO}_{2}$ & $\sqrt{ }$ & $\sqrt{ }$ \\
\hline & 1435 & $\mathrm{SiO}_{2}{ }^{*}, \mathrm{ZrSiO}_{4}{ }^{*}, \mathrm{CaO} \cdot \mathrm{MgO} \cdot 2 \mathrm{SiO}_{2}$ & $\sqrt{ }$ & $\sqrt{ }$ \\
\hline & 1450 & $\mathrm{SiO}_{2}{ }^{*}, \mathrm{ZrSiO}_{4}{ }^{*}, \mathrm{CaO} \cdot \mathrm{MgO} \cdot 2 \mathrm{SiO}_{2}$ & $\sqrt{ }$ & $\sqrt{ }$ \\
\hline \multirow{3}{*}{30} & 1350 & $\begin{array}{c}\mathrm{SiO}_{2}{ }^{*}, \mathrm{ZrSiO}_{4}{ }^{*}, \mathrm{CaSiO}_{3} \\
\mathrm{CaO} \cdot \mathrm{MgO} \cdot 2 \mathrm{SiO}_{2}\end{array}$ & $\sqrt{ }$ & $\sqrt{ }$ \\
\hline & 1375 & $\mathrm{ZrSiO}_{4}{ }^{*}, \mathrm{CaO} \cdot \mathrm{MgO} \cdot 2 \mathrm{SiO}_{2}$ & $\sqrt{ }$ & $\sqrt{ }$ \\
\hline & 1400 & $\mathrm{ZrSiO}_{4}{ }^{*}, \mathrm{CaO} \cdot \mathrm{MgO} \cdot 2 \mathrm{SiO}_{2}$ & $\sqrt{ }$ & $\sqrt{ }$ \\
\hline \multirow{3}{*}{40} & 1350 & $\mathrm{CaSiO}_{3}, \mathrm{CaO} \cdot \mathrm{MgO} \cdot 2 \mathrm{SiO}_{2}$ & $\sqrt{ }$ & $\times$ \\
\hline & 1375 & $\mathrm{CaO} \cdot \mathrm{MgO} \cdot 2 \mathrm{SiO}_{2}$ & $\sqrt{ }$ & $\times$ \\
\hline & 1400 & $\mathrm{CaO} \cdot \mathrm{MgO} \cdot 2 \mathrm{SiO}_{2}$ & $\sqrt{ }$ & $x$ \\
\hline
\end{tabular}

$\left(\mathrm{M}^{*}\right.$ represent active component; $\sqrt{ }$ represent ideal; $\times$ represent not ideal.) 
Table 4 The measured results of the silicon sensors under the different preparation conditions

\begin{tabular}{|c|c|c|c|c|c|c|c|}
\hline \multirow{2}{*}{$\begin{array}{l}\text { Actual } \\
\text { silicon } \\
\text { content } \\
\text { (wt.\%) }\end{array}$} & \multicolumn{2}{|c|}{ Preparation conditions } & \multirow{2}{*}{$\begin{array}{c}\text { Testing } \\
\text { temperature } \\
\left({ }^{\circ} \mathbf{C}\right)\end{array}$} & \multirow[b]{2}{*}{$\begin{array}{l}\mathrm{E}_{[\mathrm{Si}]} \\
(\mathrm{mV})\end{array}$} & \multirow[b]{2}{*}{$\begin{array}{c}{[\% \mathrm{Si}]_{\text {measured }}} \\
(\mathrm{wt} . \%)\end{array}$} & \multirow[b]{2}{*}{$\begin{array}{c}\text { Relative } \\
\text { error } \\
(\%)\end{array}$} & \multirow[b]{2}{*}{$\begin{array}{r}\mathrm{E}_{[\mathrm{O}]} \\
(\mathrm{mV})\end{array}$} \\
\hline & $\begin{array}{l}\text { Content of } \\
\mathrm{CaF}_{2} \text { (wt.\%) }\end{array}$ & $\begin{array}{c}\text { Sintering } \\
\text { temperature }\left({ }^{\circ} \mathrm{C}\right)\end{array}$ & & & & & \\
\hline \multirow{9}{*}{0.92} & 20 & 1400 & \multirow{9}{*}{1450} & 33 & 1.05 & 14.1 & \multirow{9}{*}{108} \\
\hline & 20 & 1400 & & 34 & 1.08 & 17.4 & \\
\hline & 20 & 1400 & & 32 & 1.03 & 12.0 & \\
\hline & 20 & 1435 & & 30 & 0.98 & 6.5 & \\
\hline & 20 & 1435 & & 35 & 1.10 & 19.6 & \\
\hline & 20 & 1435 & & 33 & 1.05 & 14.1 & \\
\hline & 20 & 1450 & & 36 & 1.12 & 21.7 & \\
\hline & 20 & 1450 & & 38 & 1.17 & 27.2 & \\
\hline & 20 & 1450 & & 34 & 1.08 & 17.4 & \\
\hline \multirow{12}{*}{0.53} & 20 & 1400 & \multirow{12}{*}{1450} & 7 & 0.51 & 3.8 & \multirow{12}{*}{85} \\
\hline & 20 & 1400 & & 6 & 0.50 & 5.7 & \\
\hline & 20 & 1400 & & 8 & 0.52 & 1.9 & \\
\hline & 30 & 1350 & & 9 & 0.54 & 1.9 & \\
\hline & 30 & 1350 & & 8 & 0.52 & 1.9 & \\
\hline & 30 & 1350 & & 7 & 0.51 & 3.8 & \\
\hline & 30 & 1375 & & 11 & 0.56 & 5.7 & \\
\hline & 30 & 1375 & & 7 & 0.51 & 3.8 & \\
\hline & 30 & 1375 & & 8 & 0.52 & 1.9 & \\
\hline & 30 & 1400 & & 10 & 0.55 & 3.8 & \\
\hline & 30 & 1400 & & 8 & 0.52 & 1.9 & \\
\hline & 30 & 1400 & & 9 & 0.54 & 1.9 & \\
\hline
\end{tabular}


Table 5 The measured results of the silicon sensors for different silicon contents in molten iron

\begin{tabular}{|c|c|c|c|c|}
\hline $\begin{array}{l}\text { Actual silicon content } \\
\qquad \text { (wt.\%) }\end{array}$ & $\mathrm{E}_{[\mathrm{Si}]}(\mathrm{mV})$ & {$[\% \mathrm{Si}]_{\text {measured }}($ wt. $\%$ ) } & $\begin{array}{c}\text { Relative error } \\
\qquad(\%)\end{array}$ & $\mathrm{E}_{[\mathrm{O}]}(\mathrm{mV})$ \\
\hline \multirow{3}{*}{0.49} & 10 & 0.44 & 10.2 & \multirow{3}{*}{95} \\
\hline & 13 & 0.47 & 4.1 & \\
\hline & 12 & 0.46 & 6.1 & \\
\hline \multirow{3}{*}{0.52} & 6 & 0.55 & 5.8 & \multirow{3}{*}{88} \\
\hline & 3 & 0.51 & 1.9 & \\
\hline & 10 & 0.61 & 17.3 & \\
\hline \multirow{3}{*}{0.92} & 33 & 1.05 & 14.1 & \multirow{3}{*}{108} \\
\hline & 29 & 0.96 & 4.3 & \\
\hline & 30 & 0.98 & 6.5 & \\
\hline \multirow{3}{*}{0.96} & 43 & 1.05 & 9.4 & \multirow{3}{*}{90} \\
\hline & 40 & 0.98 & 2.1 & \\
\hline & 37 & 0.92 & 4.2 & \\
\hline \multirow{3}{*}{1.51} & 48 & 1.44 & 4.6 & \multirow{3}{*}{97} \\
\hline & 44 & 1.33 & 11.9 & \\
\hline & 45 & 1.36 & 9.9 & \\
\hline
\end{tabular}

The optimum preparation conditions for the membrane electrode were as follows: a solid (20 wt. $\% \mathrm{CaF}_{2}+80 \mathrm{wt} . \%$ $\mathrm{SiO}_{2}$ mixed powder) to liquid (5\% PVA solution) ratio of $10 \mathrm{~g} / 10 \mathrm{~mL}$, sintering temperatures and time of $1400{ }^{\circ} \mathrm{C}$ for $30 \mathrm{~min}$. 